Journal of Geospatial Science and Technology 2 (1): 34-46, 2021

ISSN: 2756- 4088 (Online), 2408-6517(Print) doi: https://doi.org/10.54222/afrigist/jgst/v2i1.3

Submitted: August 24, 2021

Accepted: November 27, 2021

\title{
COVID-19 AND THE INTENSITY OF WATER USE AMONG HOUSEHOLDS IN JOS NORTH LOCAL GOVERNMENT AREA, PLATEAU STATE, NIGERIA
}

\author{
Andesikuteb Yakubu Ali ${ }^{1}$, Ezra Lekwot Vivan ${ }^{2}$ and Raymond Yohanna Jatau ${ }^{3}$
}

\begin{abstract}
${ }^{1}$ Department of Environmental Management, Bingham University, Karu, Nasarawa State, Nigeria.
${ }^{2}$ Department of Environmental Management, Faculty of Environmental Sciences, Kaduna State University.

${ }^{3}$ Department of Geography and Planning, University of Jos, Nigeria

Correspondence Email: andesikutebali@gmail.com
\end{abstract}

\section{ABSTRACT}

This study examined household water use intensity in the face of the current fight against COVID-19 among residents of Jos North Local Government Area, Plateau State, Nigeria. The study used both primary and secondary data. Structured questionnaire was administered on 180 household heads systematically across the selected four wards in Jos Town. While secondary data were extracted from maps and published materials. Descriptive analytical technique was applied in the study. The study revealed that 51.7\% used above 51ltr/capita/day of water during COVID-19 and 48.9\% used between 21-30ltrs/capita/day before the pandemic. There was a marked increase in water use among households in the area during COVID-19 pandemic as against the usage before COVID-19 outbreaks. The study also showed that major water use areas with higher intensity are hand washing, bathing and cloth washing with use for cooking, gardening and mopping increasing very slightly. Majority of households depended on well (53.3\%), bore hole (19.4\%) while $17.8 \%$ of the respondents relied on pipe borne water source. The study concluded that due to the fixity of water supply capacity in the area and with the increased water use in the face of the lingering pandemic, water supply capacity should be scaled up through the State Water Agency to supply more potable water to the residents in the area.

Keywords: Households, Potable water, Water Resource, Water use intensity, COVID-19

\section{COVID-19 ET L'INTENSITE DE L'UTILISATION DE L'EAU DANS LES MENAGES DANS LA JURIDICTION DE JOS NORD DANS L'ETAT DE PLATEAU, NIGERIA}

\section{RESUME}

Cette étude a examiné l'intensité de la consommation d'eau des ménages face à la lutte actuelle contre la COVID-19 chez les résidents de la zone d'administration locale de Jos North, dans l'État du Plateau, au Nigéria. L'étude a utilisé des données primaires et secondaires. Un questionnaire structuré a été systématiquement administré à 180 chefs de ménage dans les quatre quartiers sélectionnés de Jos Town. Alors que les données secondaires ont été extraites des cartes et des documents publiés. La technique d'analyse descriptive a été appliquée dans l'étude. L'étude a révélé que 51,7\% ont utilisé plus de 51 ltr/habitant/jour d'eau pendant la COVID-19 et 48,9\% ont utilisé entre 21 et 30 ltr/habitant/jour. Il y a eu une augmentation marquée de la consommation d'eau chez les ménages de la région pendant la pandémie de COVID-19 par rapport à l'utilisation avant les éclosions de COVID-19. L'étude a également montré que les principales zones d'utilisation de l'eau avec une intensité plus élevée sont le lavage des mains, le bain et le lavage des chiffons, l'utilisation pour la cuisine, le jardinage et la nivette augmentant très légèrement. La majorité des ménagesdépendaient de l'eau de canalisation $(17,8 \%)$, des puits $(53,3 \%)$ et des forages $(19,4 \%)$. L'étude a conclu qu'en raison de la fixité de la capacité d'approvisionnement en eau dans la région et de l'utilisation accrue de l'eau face à la pandémie persistante, la capacité d'approvisionnement en eau devrait être augmentée par l'intermédiaire de l'Agence nationale de l'eau pour fournir plus d'eau potable aux résidents de la région.

Mots-clés : Ménages, Eau potable, Ressource en eau, Intensité de la consommation d'eau, COVID-19

Website: www. https://afrigistjournals.com/index.php/jgst

Email: chiefeditor@afrigistjournals.com 


\section{Introduction}

Water is a unique resource however its quantity and quality vary over space and time (WHO, 2020; Adepoju and Soladoye, 2020). The amount of water required by individual varies depending on climate, standard of living, habit, their age and sex. One other factor that impinges difference in water use is the distance to the source for household uses. This condition forces women and children (especially the female child) cover many kilometers in search of safe drinking water which deprives them from engaging in productive ventures or going to school like their male counterparts (Ali, 2018). In order to reduce the hardship in getting water, the residents resort to reducing the quantity of water used in the households to far below the recommended volume and also resort to fetching water from unimproved sources like unprotected wells, ponds and streams (Gimba, 2011). Rapid population growth is one of the demographic trends that are widely affecting water resource. This has led to increase in demand for water for food production and domestic use which in turn exacerbate water shortage, food insecurity and ultimately low-level water supply. The difference in accessibility to water by various people dictates cost across different strata of consumers. The demand for water is fast outpacing its availability for consumption and the supply for various purposes and water use is seriously constrained by rising population (Araen et al., 2020). The provision of safe water, sanitation and waste management and hygienic conditions is essential for preventing and for protecting human health during all infectious disease outbreaks, including of coronavirus disease 2019 (COVID-19). Ensuring evidenced-based and consistently applied hand washing and waste management practices in communities, homes, schools, marketplaces, and healthcare facilities will help prevent human-to-human transmission of pathogens including SARSCoV-2, the virus that causes COVID-19 (Huang, Wang, Li, Ren, Zhao and $\mathrm{Hu}$ et al, 2019; WHO, 2020; WHO and UNICEF, 2020).

The COVID-19 pandemic has ravaged the economies, cities, countries, and suspected to have polluted water, air and land. The pandemic is also suspected to also further deepen and affect people and places with very poor sanitation, hygiene and water scarce areas (Cooper, 2020; Shereen et al, 2020). The hypothesis by Shereen et al (2020) has been proven that, areas with serious overcrowding problems with cholera, dysentery and other infectious diseases prevalence is also a veritable ground for the spread of COVID-19 since mode of transmission and other behavioral pattern is similar to these diseases. (Abdullahi and Abdulkadir, 2020; Cooper, 2020). Thus, slums and ghettos with crowded areas within the metropolitan areas are prone to the spread of COVID-19 and other infectious diseases.

Sustainable Development Goal 6, which focuses on clean water and sanitation, is so far off track now against the background of the Coronavirus pandemic, it is alarming to recall that 3 billion people worldwide lack basic handwashing facilities (Wambai et al, 2020; World Health Organization, 2020) and majority of the population in Jos North Local Government Area do not have access to even 
basic water supply and hand washing facilities at home. This study is aimed at determining the water use intensity in Jos North Local Government Area of Plateau State, Nigeria before and during the COVID19 pandemic. It identified the major sources of water in identified the nature and types of sanitation facilities and compared the rates of water consumption before and during the pandemic. It also assessed the severity and intensity of water use across Jos North Local Government Area of Plateau State.

\section{The study Area}

The study area (Jos North) is located between latitudes $9^{0} 50^{\prime}$ and $10^{\circ} 00^{\prime}$ North and Longitude $8^{0} 54^{\prime}$ and $9^{\circ} 00^{\prime}$ East (Figure 1). It covers an area of $340 \mathrm{~km}^{2}$ extending for about $18 \mathrm{~km}$ from the North to South and $18.5 \mathrm{~km}$ from East to West. It is bounded by Bauchi plains to the Northeast, Bassa LGA to the East and North East, Bukuru (Jos-South) to the south and Jos-East LGA to the East. Jos North is divided into 20 political wards inhabited by various ethnic nationalities (both foreign and local), with an estimated human population of about 437,217 (NPC 2006) and projected to be 605,983 in 2020.

The geology of the area is largely made up of younger granite complex. Shoeneich (1991) observed that the Jos Plateau consists of an undulating dissected surface highest in the South and slopping Northwards with an area of about $9,400 \mathrm{~km}^{2}$. The highest peak is at Shere hills which rise to $1,777 \mathrm{~m}$ while the gently undulating surface lies between $915 \mathrm{~m}$ and $1,300 \mathrm{~m}$. The two aquifers in existence are fracture crystalline aquifer and the soft overburden aquifer. The Climate is affected by altitude and changing position of inter- Tropical convergence zones (ITCZ) or inter Tropical Discontinuity or Inter-Tropical Front (ITF). Rainfall is high $(1,305 \mathrm{~mm})$ and characterized by two distinct seasons (wet and dry) with temperature range of $32^{\circ} \mathrm{c}$ to $18^{\circ} \mathrm{c}$ respectively (Ali, 2018).

The climate of the Jos Plateau is primarily controlled by the position and altitude of the Plateau relative to the general circulation of the major air Masses-Tropical maritime (MT) and tropical continental air masses (CT) (Daloeng, 2019). Accordingly, rainfall amount increases towards the south with altitude. The rainfall regime shows one maximum usually in July. The climate is characterized by two distinct seasons, the rainy season and dry season. The rainy season which spans from April to October is marked by frequent thunder storms of high intensity and annual rainfall. The dry season ranges between November and March, this is marked by the Southward movement of the ITD, during which the Climate is dominated by the CT air mass. Minimum temperature often drops below $15^{\circ} \mathrm{c}$ but start rising again from the months of February and March. High temperatures are recorded in the months of March-May, while the lowest temperatures popularly called the harmattan month is experienced between December and January (Beka, 2019). 


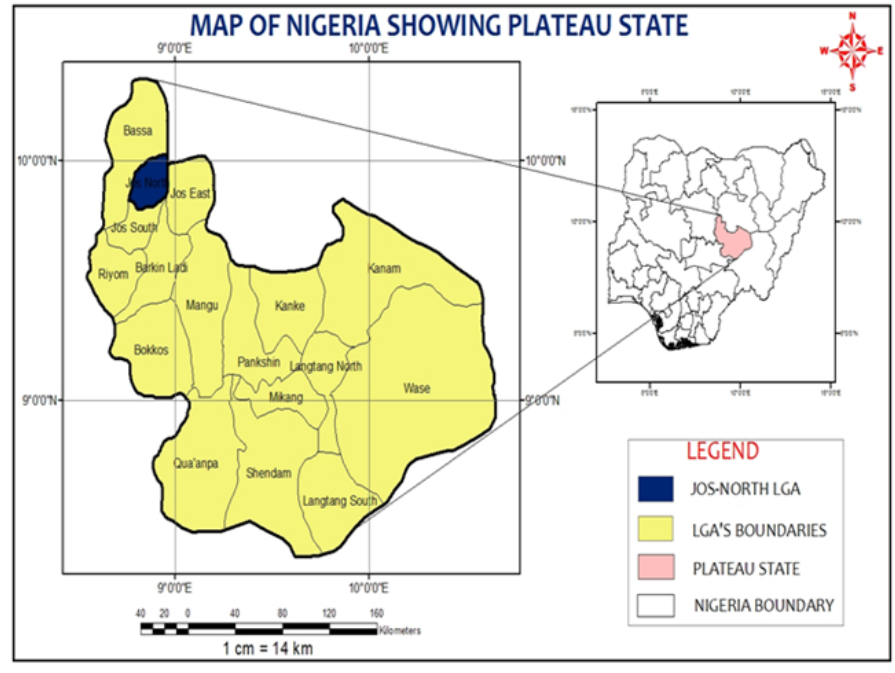

Figure 1: Map of Nigeria showing Jos North LGA, Plateau State

\section{Methodology}

Data used were obtained from households being the study units. Field techniques such as questionnaire administration and interviews were undertaken while the secondary data was sourced from institutional records, published reports and research works related to COVID-19 and water use intensity. Jos North consists of twenty electoral wards. They are as follows: Abanashewu, Ahwol, Ali Kazaure, Angwan Rogo, Apata, Garba Daho, Gangare, Ibrahim Katsina, Jenta Adamu, Jos Jarawa, Karbong, Lamingo, Maza, Naraguta A, Naraguta B, Sarkin Arab, Tafawa Balewa, Targon, Tudun wada and Vendapuye respectively.

The researchers chose $20 \%$ of the total number of wards in Jos North. Hence, a total sample size of 180 households was determined from the aggregation of the respective samples of each ward. Using 20\% sampling, four wards were selected using stratified sampling after arranging the twenty wards alphabetically. Also 10\% sample size was adopted in each of the four wards using the number of houses in each neighborhood area in the four wards to get the total number of 180 structured questionnaires that were administered across the four wards.

Twenty ward heads were interviewed due to their experience and long duration of stay and their views used in supporting the responses elicited from the administered questionnaire in the sampled wards. The data collected and used for the study included water access levels, respondent's perception on water scarcity and the severity of water use in the area. In order to ensure adequate coverage and fair representation in the sample selection, the lists of settlements in the region from the area and the administrative map of Plateau State verified during reconnaissance survey were systematically selected by arranging every settlement in each of the wards and systematically chose households heads which formed 10\% sample size. Data were analysed using descriptive statistics which include frequency and percentage distribution.

\section{Results and Discussion}

Covid-19 has affected every facet of life globally with emphasis on sanitation and personal hygiene as measures to curb the spread of the virus, the quantum of water use is expected to also increase (Olabamiji and Ajala, 2020). Most households in rural, semiurban and urban areas would need to double their quantity of water supply for hand washing, dish washing, cloth washing and for sanitation to cope with daily need and demand for water sanitation and hygiene facilities (Ali et al, 2020). Daily water demand by individuals in Jos, Plateau State, Nigeria was put at 30-120 litres per day per 
capita depending on the water availability, educational level of user and the culture of water use. The pandemic with its attendant lockdown imposed by government of Plateau State confined all members of households within homes for a very long time. This has increased the volume of water use for toilet flushing, cooking, washing, drinking and bathing (Ali, 2020).

Table 1 shows that nearly all the households and $46.7 \%$ are connected to the State Water grid. The remaining 53.3\% are connected to other water supply sources. Over $23 \%$ of the respondents have house connections, $33.3 \%$ have stand pipes within their dwellings and $25.6 \%$ have stand pipes outside their dwellings. These connections have existed between 1-10 years (18.3\%), 1120 years $(23.3 \%)$ and above 31 years $(43.3 \%)$, this means that majority of the respondents surveyed had spent up to between 21-30 years in their current apartments and are connected to the pipe borne water system due to the following reasons: health reliability $(30.6 \%)$, modernization (21.1\%), insufficiency of alternate sources (22.8\%), others which constitute $20.6 \%$ are of the view that all of the stated reasons led them into getting connected to the piped water network system,(see Table 1).

In spite of the residents' connections to the pipe water supply network, pipe borne water is not their primary source of water due to erratic nature of supply and so depended on other sources to meet their potable water needs. Those that depend on well water in Table 2 constitute $53.3 \%$ of the household heads surveyed in all districts, $19.44 \%$ drilled and used bore holes either within their dwellings or get water of this source from their neighbourhood, $4.4 \%$ of the respondents source their water from vendors and 3.33\% depend on surface water sources such as streams and ponds for drinking, cooking and washing. Getting water from other means outside public supply comes with huge cost to residents of Jos metropolis. Ali (2018) had earlier asserted that more than fifty percent (51.9\%) of residents spent about $3-4 \%$ of their incomes to defray the cost of water on a monthly basis, $16.0 \%$ of the residents use 5 $6 \%$, another $6 \%$ spent more than $6 \%$ of their income on water on monthly basis. Only about $26 \%$ of resident spent between $1-2 \%$ on monthly income on water provision (Ali, 2018).

Table 1: Respondents' Connection Status Water Supply System and Reason

\begin{tabular}{|c|c|c|c|}
\hline Variable & Classes & Frequency & Percentage \\
\hline \multirow{3}{*}{ Connection to State Water grid } & Yes & 84 & 46.67 \\
\hline & No & 96 & 53.33 \\
\hline & Total & 180 & 100.0 \\
\hline \multicolumn{4}{|l|}{ Years of connection } \\
\hline & $1-10$ & 33 & 18.33 \\
\hline & $11-20$ & 42 & 23.33 \\
\hline & $21-30$ & 27 & 15.00 \\
\hline & Over 31 & 78 & 43.33 \\
\hline & Total & 180 & 100.0 \\
\hline \multicolumn{4}{|l|}{ Connection Reasons } \\
\hline & Health reliability & 55 & 30.56 \\
\hline & Modernization & 38 & 21.11 \\
\hline & $\begin{array}{l}\text { Insufficiency of } \\
\text { alternate sources }\end{array}$ & 41 & 22.78 \\
\hline & All of the above & 37 & 20.56 \\
\hline & Others & 9 & 5.00 \\
\hline & Total & 180 & 100.0 \\
\hline \multicolumn{4}{|l|}{ Type of Connection } \\
\hline & $\begin{array}{l}\text { House } \\
\text { connection }\end{array}$ & 42 & 23.33 \\
\hline & $\begin{array}{l}\text { Stand pipe } \\
\text { within dwelling }\end{array}$ & 60 & 33.33 \\
\hline & $\begin{array}{l}\text { Stand pipe } \\
\text { outside dwelling }\end{array}$ & 46 & 25.56 \\
\hline & Others & 32 & 17.77 \\
\hline & Total & 180 & 100.0 \\
\hline
\end{tabular}


Assessment of water demand for domestic use among the residents on a daily basis revealed that $68.33 \%$ of the respondents required between 51-100 litres per day, another $24.44 \%$ required $10-50$ litres per day. While, $7.2 \%$ required more than 100 litres per day (Table 2). This in a way reflect the variation in household size and nature of economic activities across the study area. The findings also corroborate Ali (2018) conclusion that water demand of households vary with the size of households, nature of economic activities within the homes, water availability, the nature and number of sanitation facilities within dwellings area (Ali, 2018).

On reasons for increased water usage for improved sanitation and hygiene by residents showed that $39.4 \%$ attributed increased water usage to COVID-19 pandemics like COVID19, Ebola virus disease and Lassa fever which required regular washing of their hands, bath and regular sanitation (keep clean) to frequently avoid contracting corona virus. Only $6.7 \%$ claimed they are accustomed to their normal healthy living habit of keeping themselves and their immediate environment clean.

Other reasons also revolved around improved sanitary and hygiene conditions such as clean and well-kept environment (6.1\%), prevention of other infectious diseases, $(5 \%)$, prevention of risk of exposure to environmental hazards $(4.4 \%)$, increased public health monitoring and environmental education $(11 \%)$ respectively.
Table 2: Primary and Alternate Water Sources of Respondents

\begin{tabular}{|c|c|c|c|}
\hline Variable & Water Source & Frequency & Percentage \\
\hline \multirow[t]{7}{*}{ Primary Water source } & Pipe borne wate & 32 & 17.78 \\
\hline & Well & 96 & 53.33 \\
\hline & Borehole & 35 & 19.44 \\
\hline & Vendor & 8 & 4.44 \\
\hline & Surface water & 6 & 3.33 \\
\hline & Others & 3 & 1.67 \\
\hline & Total & 180 & 100.0 \\
\hline \multicolumn{4}{|l|}{ Alternate water sources } \\
\hline & Well & 33 & 18.33 \\
\hline & Borehole & 46 & 25.56 \\
\hline & Stream & 15 & 8.33 \\
\hline & Rainfall & 31 & 17.22 \\
\hline & Pipe borne wate & 52 & 28.89 \\
\hline & Total & 180 & 100 \\
\hline \multicolumn{4}{|c|}{ Nature of sanitation facilities } \\
\hline & Toilets \& sinks & 55 & 30.56 \\
\hline & Latrines & 57 & 31.66 \\
\hline & $\begin{array}{l}\text { Showers \& } \\
\text { baths }\end{array}$ & 42 & 23.33 \\
\hline & $\begin{array}{l}\text { Wash hand } \\
\text { basin }\end{array}$ & 26 & 14.44 \\
\hline & Total & 180 & 100.0 \\
\hline \multicolumn{4}{|l|}{ Water quantity needed } \\
\hline & 10-50litres & 44 & 24.44 \\
\hline & $51-70$ litres & 38 & 21.11 \\
\hline & 71-80 litres & 40 & 22.22 \\
\hline & 81-100litres & 45 & 25.00 \\
\hline & over 101litres & 13 & 7.22 \\
\hline & Total & 180 & 100.0 \\
\hline
\end{tabular}

In-depth interview with ward heads also corroborates the findings that increasing water demand is already a burden to the residents in the face of limited quantity of water available and the demand of COVID19 protocol. Thus, they have to resort to exploring other water sources to cope and bridge these shortfalls. 
Table 3: Reasons for Improvement in Sanitary and Hygienic Conditions

\begin{tabular}{|l|l|l|l|}
\hline S/no & Nature of water use & Frequency & $\%$ \\
\hline & COVID-19 & 71 & 39.44 \\
\hline & Healthy living & 12 & 6.67 \\
\hline & $\begin{array}{l}\text { Clean and well-kept } \\
\text { environment }\end{array}$ & 11 & 6.11 \\
\hline & $\begin{array}{l}\text { Prevention of other } \\
\text { infectious disease }\end{array}$ & 9 & 5.00 \\
\hline & $\begin{array}{l}\text { Risk of exposure to } \\
\text { hazards }\end{array}$ & 8 & 4.44 \\
\hline & $\begin{array}{l}\text { Increase in public } \\
\text { health }\end{array}$ & 13 & 7.22 \\
& $\begin{array}{l}\text { Environmental } \\
\text { Education } \\
\text { (Education example) }\end{array}$ & 7 & 3.89 \\
\hline & All of the above & 49 & 27.22 \\
\hline & Total & 180 & 100 \\
\hline
\end{tabular}

In Table 4 , over $46 \%$ of the respondents surveyed in Jos North strongly agreed that there is an intensive water use during the COVID-19 pandemic, $35.56 \%$ agreed that there is intensive water using during this period and $11.67 \%$ of the respondents said they are not aware of any increase or decrease in the quantity of water usage across all the districts of Jos North LGA only $5 \%$ and $7 \%$ disagreed and agreed respectively that there is intensive water use in the area. This insignificant group of respondents may belong to those battling with water scarcity and hardly had water for consumptive use not to talk of having the luxury of hand washing and additional time and quantity of water for bathing, washing and general cleaning. On the severe use of water during the pandemic $53.89 \%$ said that they use water very intensively now 53 said that they use water very intensively now than the period before COVID-19. 36.1\% are of the view that they use water intensively in Jos North for consumptive use, sanitation and hygiene and only $10 \%$ did not engage in intensive water use at this time.

About $49 \%$ of the respondents said they use 21 - 30 liters daily before the period of the pandemic. This is followed by $17.2 \%$ of the respondents in Jos North Local Government Area who said that they depend on only 31-40 liters of water daily for all household uses, $7.8 \%$ live on the quantity of 1-10 liters. All these falls below the real water consumption rate of $50-80$ liters and also below the policy threshold of 120 liters/capita/day in Jos city. Over $51 \%$ of the respondents are of the view that they live on more than 51 liters per capita per day within the area. This to some extent is consistent with the real consumption rate within the area. Other said they consume 41-50 liters (13.9\%), 31 - 40 liters (12.78\%), 21 - 30 liters (16.67\%), $11-20$ liters (4.4\%) and $1-$ 10 liters $(1.6 \%)$ with this unacceptable water supply rate and available the resident of the area have to obey other COVID-19 protocols to be able to win the war against the pandemic.

Table 5 shows the severity and intensity of water use across the districts of Jos North LGA, Plateau State. Hand washing became seriously intensified by most households in the area as $34.4 \%$ of the respondents agreed that they wash their hands very well and many times in a day due to the prevalence of the dreaded COVID-19 pandemic. Cloth washing (19.4\%), bathing (16.7\%), toilet flushing (9.4\%) and dish washing (3.9\%) are the highest lines of water consumption. 
Table 4: Intensity and Quantities of Water Used Before and During COVID-19 in Jos North

\begin{tabular}{|c|c|c|c|}
\hline S/no & Parameter & Frequency & $\%$ \\
\hline & $\begin{array}{l}\text { Intensive use of water } \\
\text { during COVID-19 } \\
\text { Strongly Agreed } \\
\text { Agreed } \\
\text { Undecided (don't know) } \\
\text { Strongly disagreed } \\
\text { Disagreed }\end{array}$ & $\begin{array}{l}83 \\
64 \\
21 \\
5 \\
7\end{array}$ & $\begin{array}{l}46.11 \\
32.56 \\
11.67 \\
2.78 \\
7\end{array}$ \\
\hline & $\begin{array}{l}\text { Severe use of water during } \\
\text { COVID-19 } \\
\text { Very Intensive } \\
\text { Intensive } \\
\text { Less intensive }\end{array}$ & $\begin{array}{l}97 \\
65 \\
18\end{array}$ & $\begin{array}{l}53.89 \\
36.11 \\
10\end{array}$ \\
\hline & $\begin{array}{l}\text { Quantum use of water } \\
\text { Before COVID-19 } \\
1-10 \text { liters } \\
11-20 \text { liters } \\
21-30 \text { litres } \\
31-40 \text { liters } \\
41-50 \text { liters } \\
\text { Above } 51\end{array}$ & $\begin{array}{l}14 \\
22 \\
88 \\
31 \\
7 \\
18\end{array}$ & $\begin{array}{l}7.78 \\
12.22 \\
48.89 \\
17.22 \\
3.89 \\
10\end{array}$ \\
\hline & $\begin{array}{l}\text { Quantum use of water } \\
\text { during COVID-19 } \\
1-10 \text { liters } \\
11-20 \text { liters } \\
21-30 \text { litres } \\
31-40 \text { liters } \\
41-50 \text { liters } \\
\text { Above } 51\end{array}$ & $\begin{array}{l}19 \\
8 \\
12 \\
23 \\
25 \\
93\end{array}$ & $\begin{array}{l}10.56 \\
4.44 \\
6.67 \\
12.78 \\
13.89 \\
51.67\end{array}$ \\
\hline & Total & 180 & 100 \\
\hline
\end{tabular}

While the water use for car washing, drinking, cooking, flower watering and general household cleaning remain low based on respondents' views. On quantity of water used for varied reasons, before the pandemic, Table 4 shows that majority respondents of $48.9 \%$ agree that only 21-30 liters per day per capita was used for both consumption and hygiene purposes. Those who consume above 51 liters per capita are just 10\%. All these fall below the real daily water consumption threshold of 50-80 liters per capital per day. During COVID-19 pandemic, over $51 \%$ of the respondents also said that there is sharp increase in the rate and intensity of water use in the area. This is attributable to the high frequency and rate of water use for bathing, hand washing, toilet flushing and others.

There were major differences in water use quantities between piped and unpiped households anywhere. Olorunleke (2015) indicates that one of the reasons of different water quantity usage by the people of Jos North is the presence of water appliances in piped households (e.g, flush toilet, baths and showers) which accounted for considerable quantities of water use. On the average, 64\% of piped households in the study area have flushed toilets using an average of 19.2 liters of water per capita per day. But the figures were underestimated because not all of the interviewers were able to record their data. Water supply and sanitation in Nigeria, the largest African country and the continent's biggest oil exporter, is characterized by low levels of access to an improved water sources and limited access to improved sanitation (WHO, 2010; Gbadegesin and Akintola, 2020).

The total quantity of water obtained from different sources in the four wards amounted to about 45,050 litres per day, with Jos Jarawa and Naraguta B having the highest percentage of $27.7 \%(12,490)$ litres and $26.9 \%(20,100$ litres $)$ respectively. Also about $24.7 \%(11,100$ litres $)$ quantity of water obtained in Lamingo ward, a smaller proportion of water is obtained in Tafawa Balewa $20.7 \%$ of the respondents (9,360litres) (Olorunleke, 2015). According to Olorunleke (2015), cooking consumes the highest amount of water used for domestic purpose (10.872 lites) per day, while bathing 
constitutes the second highest user of water for domestic purpose (9,187 litres) per day in the wards. Also laundering amounted to (6,906 litres) of domestic water use. The amount of water use for flushing (4.373 litres) (3.594 litres), (3,432 litres respectively per day in the wards. But for the per capita water use in the areas preCOVID-19, Olorunleke (2015) put the water use quantities at drinking (4litres), cooking (10litres), laundering (6.37litres), bathing (8.46litres), toilet flushing (5.52litres), flower watering (3.17litres) and car washing (3.31litres). This gross water underutilization shows the deep seated water shortage and the groaning of the residents in the area.

One of the most effective ways to slow down transmission of Coronavirus (COVID-19) is to wash or sanitize our hands. However, 4.2 billion, or $55 \%$ of the world's population, do not have access to even basic hand washing facilities at home. Lack of access to clean water affects vulnerability to disease and ill health. It is especially acute among those living in extreme poverty in rural areas, as well as in informal urban settlements (WMO, 2020a and WMO, 2020b). According to the latest reports, climate change will affect the availability, quality and quantity of water needed for basic human needs, thus undermining enjoyment of the basic rights to safe drinking water and sanitation for billions of people (Beka, 2020).

Table 6 depicts the different areas of water use to include hand washing, cloth washing, bathing and toilet flushing which constitute the major areas of sanitation and personal hygiene.
Table 5: Severity and Intensity of Water Use Across Jos North LGA

\begin{tabular}{|c|l|c|c|}
\hline- & Nature of water use & Frequency & $\%$ \\
\hline & Hand washing & 62 & 34.44 \\
\hline & Cloth washing & 35 & 19.44 \\
\hline & Bathing & 30 & 16.67 \\
\hline & Toilet flushing & 17 & 9.44 \\
\hline & Dish washing & 7 & 3.89 \\
\hline & $\begin{array}{l}\text { General household } \\
\text { cleaning }\end{array}$ & 3 & 1.67 \\
\hline & Car washing & 14 & 7.78 \\
\hline & Drinking & 11 & 6.11 \\
\hline & Cooking & 10 & 5.56 \\
\hline & Flower watering & 6 & 3.3 \\
\hline & Total & 180 & 100 \\
\hline
\end{tabular}

The number of times individuals wash their hands preCOVID-19 was only three times and this number increased to more than 12 times during the pandemic. An interview with most of the respondents validated this position and asserted that it is only when people are ready to eat that they wash their hands. The quantity increased from 4litres in 50 seconds preCOVID-19 to over 13litres in 5minutes during the pandemic. Washing of clothes was a routine carried out once in a day in the area but due to the fear of infection, most respondents tend to wash their clothes upon their return from offices, markets and other public places using an increase of water use quantity from 40litres (within the estimated duration of 2hours) to 1201tres in 3hours. On bathing, most individuals interacted said they had to switch from 1 diet to 3 times a day on a per capita water use of 10 litres to 30litres using cumulative of 15 minutes. 
Table 6: Water Use by individuals in Households Before and during COVID-19

\begin{tabular}{|c|c|c|c|}
\hline $\mathbf{S} / \mathbf{N}$ & Indicator & $\begin{array}{l}\text { Standard } \\
\text { Desired (\%) } \\
\text { level (Before } \\
\text { Covid) }\end{array}$ & $\begin{array}{l}\text { PSWB } \\
\text { Actual } \\
\text { (\%) } \\
\text { (During } \\
\text { COVID- } \\
\text { 19) }\end{array}$ \\
\hline \multirow[t]{4}{*}{1.} & Hand washing & & \\
\hline & $\begin{array}{l}\text { (a) No of times in a } \\
\text { day }\end{array}$ & 3 & 12 \\
\hline & $\begin{array}{l}\text { (b) Estimated water } \\
\text { Quantity used }\end{array}$ & 41 trs & 13ltrs \\
\hline & (c) Duration of use & 50 seconds & $5 \mathrm{mins}$ \\
\hline \multirow[t]{4}{*}{2.} & Cloth Washing & & \\
\hline & $\begin{array}{l}\text { (a) No of times in a } \\
\text { day }\end{array}$ & 1 & 2 \\
\hline & $\begin{array}{l}\text { (b) Estimated water } \\
\text { Quantity used }\end{array}$ & 401 trs & 120ltrs \\
\hline & (c) Duration of use & $2 \mathrm{hrs}$ & $3 \mathrm{hrs}$ \\
\hline \multirow[t]{3}{*}{3.} & Bathing & & \\
\hline & $\begin{array}{l}\text { (a) No of times in a } \\
\text { day }\end{array}$ & 1 & 3 \\
\hline & $\begin{array}{l}\text { (b) Estimated water } \\
\text { Quantity used } \\
\text { (c) Duration of use } \\
\text { 9mins }\end{array}$ & 10ltrs & $\begin{array}{l}301 \mathrm{ltrs} \\
15 \mathrm{mins}\end{array}$ \\
\hline \multirow[t]{4}{*}{4.} & $\begin{array}{l}\text { Toilet Flushing and } \\
\text { Cleaning }\end{array}$ & & \\
\hline & $\begin{array}{l}\text { (a) No of times in a } \\
\text { day }\end{array}$ & 5 & 8 \\
\hline & $\begin{array}{l}\text { (b) Estimated water } \\
\text { Quantity used } \\
\text { (c) Duration of use }\end{array}$ & 52ltrs & 74ltrs \\
\hline & & $9 \mathrm{mins}$ & $20 \mathrm{mins}$ \\
\hline
\end{tabular}

Toilet flushing was done 5 times preCOVID-19 using an estimated quantity of 52 litres in 9 minutes to 8 times in twenty minutes using 74litres of water.

Dish washing which hitherto was carried out three times a day just increased by 1 and the 20litres in twenty minutes has increased to 281 itres in 30 minutes in Table 7. During the lockdown and by extension the pandemic, more time is being spent at home as people cut down interactions and unnecessary visits to a lot of public places. Also, not much increase is witnessed in the area of general house cleaning. The number of times just increased by one, from ten litres used preCOVID-19 to 18litres during the pandemic with a double increase in the time used for the cleaning exercise. Drinking improved water in the right quantity at the right time enhances the health of individuals. From 6 times, one litre of water consumption by individuals in a day preCOVID-19 pandemic to 9 times on the average daily on 1.5litres on a varied number of times in both cases depending on weather and other condition. Cooking is carried out thrice daily to provide the three-square meals for the members of the households. But during lockdown and the pandemic, cooking was done up to four times using an additional 5litres from the 10litres used preCOVID-19 using 1hours 40minutes from the one hour that was previously used.

But in Jos North Local Government as depicted in Table 7, water use quantity for hygiene services has increased by more than $50 \%$ due to the increase in the frequency of hand washing, bathing, cloth washing and laundering, cleaning and toilet flushing. The water for consumptive use has not experienced appreciable change as the fight against COVID-19 places much emphasis on hand washing and personal hygiene and sanitation as against water consumption. Water use has increased sixfold over the past century and is rising by about $1 \%$ a year. However, it is estimated that climate change, along with the increasing frequency and intensity of extreme events - storms, floods and droughts, will aggravate the situation in countries already currently experiencing 'water stress' and generate similar problems in areas that have not been severely affected. 
Furthermore, the report highlights the fact that poor water management tends to exacerbate the impacts of climate change, not only on water resources but on society as a whole (WMO, 2020b and FRN, 2010).

Table 7: Water Use by individuals Household Before and During COVID-19

\begin{tabular}{|c|c|c|c|}
\hline $\mathrm{S} / \mathrm{N}$ & Indicator & $\begin{array}{l}\text { Standard } \\
\text { Desired (\%) } \\
\text { level } \\
\text { (Before } \\
\text { Covid) }\end{array}$ & $\begin{array}{l}\text { PSWB } \\
\text { Actual (\%) } \\
\text { (During } \\
\text { COVID- } \\
19)\end{array}$ \\
\hline \multirow[t]{4}{*}{1} & Dish washing & & \\
\hline & $\begin{array}{l}\text { (d) No of times in a } \\
\text { day }\end{array}$ & 3 & 4 \\
\hline & $\begin{array}{l}\text { (e) Estimated water } \\
\text { Quantity used }\end{array}$ & 20ltrs & 281 trs \\
\hline & (f) Duration of use & $20 \mathrm{mins}$ & $30 \mathrm{mins}$ \\
\hline \multirow[t]{4}{*}{2} & $\begin{array}{ll}\text { General Household } & \text { Heaning }\end{array}$ & & \\
\hline & $\begin{array}{l}\text { (d) No of times in a } \\
\text { day }\end{array}$ & 1 & 2 \\
\hline & $\begin{array}{l}\text { (e) Estimated water } \\
\text { Quantity used }\end{array}$ & 10ltrs & 181trs \\
\hline & (f) Duration of use & $20 \mathrm{mins}$ & $40 \mathrm{mins}$ \\
\hline \multirow[t]{3}{*}{3} & Drinking & & \\
\hline & $\begin{array}{l}\text { (d) No of times in a } \\
\text { day }\end{array}$ & 6 & 9 \\
\hline & $\begin{array}{l}\text { (e) Estimated water } \\
\text { Quantity used } \\
\text { (f) Duration of use }\end{array}$ & $\begin{array}{l}11 \mathrm{tr} \\
\text { varied }\end{array}$ & $\begin{array}{l}1.51 \text { trs } \\
\text { Varied }\end{array}$ \\
\hline \multirow[t]{4}{*}{4} & Cooking & & \\
\hline & $\begin{array}{l}\text { (d) No of times in a } \\
\text { day }\end{array}$ & 3 & 4 \\
\hline & $\begin{array}{l}\text { (e) Estimated water } \\
\text { Quantity used } \\
\text { (f) Duration of use }\end{array}$ & 10ltrs & 15ltrs \\
\hline & & $1 \mathrm{hr}$ & $1 \mathrm{hr} 40 \mathrm{mins}$ \\
\hline
\end{tabular}

\section{Conclusion}

COVID19 pandemic has changed daily life of people in Jos North LGA, Plateau State and around the world. The impact on social life, economic activities and the environment is obvious. In addition, with changes in daily life, the demand for water may not only change in volume rate, but also between user groups such as households and economic sectors. This in turn, will result in a spatial change in the service area and may require water providers to carry out architectural planning due to the uneven distribution of households and economic sectors. This study found that the daily water consumption during the lockdown in 2020 was increased in the same period in previous years. It was concluded that for water supply companies and similar service providers, an important question is whether behavioral changes will continue beyond the COVID19 period.

Based on the forgoing, the study recommends thus: (i) the government should strengthen the State Water Agency to supply more potable water to the residents in order to reduce time spent on travelling to fetch water from the streams, ponds, rivers, neighbours and other sources (ii) residents should embark on provision of alternate water sources to meet up with their water demand (iii) residents should live responsibly in obedience to other COVID-19 protocols to bridge the gap created by water shortage in the area.

\section{References}

Abdullahi, A. H and Abdulkadir, M (2020).

An Analysis of Corona Virus Disease Transmission in Relation to Temperature Variability in Nigeria. Proceedings of the Special Virtual Conference on Covid-19 organized by the South West Association of Nigerian Geographers 2020 
Adepoju, O and Soladoye, O (2020). Geospatial Enabling Strategies for Timely Containment of Covid-19 Pandemic in Lagos State. Proceedings of the Special Virtual Conference on Covid-19 organized by the South West Association of Nigerian Geographers 2020

Ali, A.Y (2020). Analysis of Socioeconomic Benefits of Water Supply Projects to Users in Jos Metropolis, Nigeria. FUTY Journal of Environment, 14 (2), 2020

Ali, A.Y (2018). Cost Benefit analysis of water supply projects in Jos metropolis, Nigeria. An unpublished $\mathrm{PhD}$ Thesis submitted to Department of Geography and Planning, University of Jos.

Araen, A.S, Ali, A.Y, Vivan, E.L, Obasi, M.T and Giwa, C.Y (2020). Water Scarcity among Households and the Fight against COVID-19 in Jalingo Town, Taraba State, Nigeria. Proceedings of the Virtual Conference of the South West Association of Nigerian Geographers.

Beka, N.C (2020). Spatial Variation of Groundwater Quality in the Greater Jos Urban Area, Nigeria. A PhD Progress Report Submitted to Department of Geography and Planning, University of Jos, Jos Nigeria

Cooper, R (2020) Water security beyond Covid-19. Helpdesk Report University of Birmingham, United Kingdom.
Daloeng, H.M (2019). Climate Variability and Prevalence of Diseases in Plateau State, Nigeria. An unpublished $\mathrm{PhD}$ Thesis submitted to Department of Geography and Planning, University of Jos, Nigeria

FRN (Federal Republic of Nigeria), (2010). Nigeria at $50^{\text {th }}$. A Compendium. The official and Authoritative book about Nigeria. Pp 612-613.

Gbadegesin, O.A and Akintola S. O (2020). Legal Perspective on the Impact of Covid-19 Interventions on Environment and Human Health in Nigeria. Proceedings of the Special Virtual Conference on Covid-19 organized by the South West Association of Nigerian Geographers 2020

Gimba 2011. Assessment of quality of drinking water in Bosso town, Niger State. Department of Community Medicine, Faculty of Medicine Ahmadu Bello University, Zaria Nigeria.

National Population Commission, (2006). Federal Republic of Nigeria, official Gazette, vol.96, No.2, B (23). Abuja: Federal Government Printer.

Olabamiji, A and Ajala, O (2020). Covid-19 Lockdown Effects, Resilience, Adaptation and Coping Strategies in Nigeria. Proceedings of the Special Virtual Conference on Covid-19 organized by the South West Association of Nigerian Geographers 2020Olorunleke, G.F (2015). Managing Water demand in Jos North Local Government Area, Plateau State. An Unpublished MSc Thesis Submitted to Department of Geography and Planning University of Jos, Nigeria 
Schoeneich, K. (1991). Physical and Chemical properties of water. In Geology of the Jos Plateau and Yankari Game Reserve, Schoeneich, K., and Mbodo, W. C. (Eds), Jos University Press Ltd, P52-60.

Shereen, M.A, Khan, S., Kazmi, A., Bashir, N \& Siddique, R. (2020) Covid19 Infection: Origin, Transmission and Characteristics of Human Corona viruses. Journal of Advanced Research. 24 (1) $91-98$

Wambai, M.W, Ali, A.Y, Vivan, E.L, Daloeng, H.M, Obasi, M.T and Giwa, C.Y (2020). Assessment of Access to Toilet Facilities and its Health Implications in Toro Local Government Area, Bauchi State, Nigeria, Bima Journal of Science and Technology, 4 (1)

WHO (2010): Safe Water and Global Health. Geneva, Switzerland http://www.who.in/f eactures/ag/70/en/ Accessed November 202019

WHO (2020) Water, sanitation, hygiene, and waste management for the COVID-19 virus. Interim guidance. Geneva, Switzerland https://www.who.int/publications/ i/item/WHO-2019-nCoV-IPCWASH-2020.4 Accessed September 20, 2020
WHO/UNICEF, (2010), Progress on Sanitation and Drinking Water 2010 Update. WHO/UNICEF Joint Monitoring Programme for Water Supply and Sanitation. WHO/UNICEF, Geneva, Switzerland http://whqlibdoc.who.int/publicat on/2010. Accessed November 20, 2019, $8.56 \mathrm{pm}$

World Meteorological Organization (2020a). Water challenge: clean water for handwashing.https://public.wmo.int/ en/resources/coronavirus-covid19/water Accessed September 4, 2020

World Meteorological Organization (2020b). WMO chief: Accelerate action on Sustainable Development Goal on Water.https://public.wmo.int/en/med ia/news/wmo-chief-accelerateaction- sustainable-developmentgoal-water Accessed September 4, 2020 